\title{
Hydrogen Sulfide Acts as a Fungicide to Alleviate Senescence and Decay in Fresh-cut Sweetpotato
}

\author{
Jun Tang ${ }^{1}$ \\ Xuzhou Sweet Potato Research Center, National Sweet Potato Improvement \\ Center, Xuzhou, 221131, China
}

Kang-Di Hu ${ }^{1}$, Lan-Ying Hu, Yan-Hong Li, Yong-Sheng Liu, and Hua Zhang ${ }^{2}$ School of Biotechnology and Food Engineering, Hefei University of
Technology, Tunxi Road 193, Hefei, 230009, China

Additional index words. antioxidant enzyme, fungal spoilage, lipid peroxidation, nutrient, postharvest

\begin{abstract}
Hydrogen sulfide $\left(\mathrm{H}_{2} \mathrm{~S}\right)$ has been shown to be a gaseous molecule in the regulation of many processes in plants such as abiotic stress tolerance, root organogenesis, stomatal movement, and postharvest fruit senescence. We studied the role of $\mathrm{H}_{2} \mathrm{~S}$ in the regulation of senescence and fungal decay in fresh-cut sweetpotato (Ipomoea batatas L., cv. Xushu 18) roots. $\mathrm{H}_{2} \mathrm{~S}$ donor sodium hydrosulfide (NaHS) alleviated senescence in fresh-cut sweetpotato root tissue in a dose-dependent manner with the optimal concentration of 2.0 mmol $\cdot \mathrm{L}^{-1} \mathrm{NaHS}$ solution. At the optimal concentration of $2.0 \mathrm{mmol} \cdot \mathrm{L}^{-1} \mathrm{NaHS}, \mathrm{H}_{2} \mathrm{~S}$ fumigation maintained higher levels of reducing sugar in sweetpotato fresh-cut root. $\mathrm{H}_{2} \mathrm{~S}$ treatment also significantly increased the activities of guaiacol peroxidase (POD) and decreased those of polyphenol oxidase (PPO) in sweetpotato during storage. Further investigation showed that $\mathrm{H}_{2} \mathrm{~S}$ treatment maintained a lower level of lipoxygenase (LOX) activity compared with water control. Consistently, the accumulation of malondialdehyde (MDA) was reduced in $\mathrm{H}_{2} \mathrm{~S}$-treated groups. Three fungal pathogens, Rhizopus nigricans, Mucor rouxianus, and Geotrichum candidum, were isolated from sweetpotato tissue infected with black rot or soft rot. $\mathrm{H}_{2} \mathrm{~S}$ fumigation at 1 to $2.5 \mathrm{mmol} \cdot \mathrm{L}^{-1} \mathrm{NaHS}$ resulted in effective inhibition of the three fungi when grown on medium. When the three fungi were inoculated on the surface of sweetpotato slices, $\mathrm{H}_{2} \mathrm{~S}$ fumigation greatly reduced the percentage of fungal infection. In conclusion, these data suggest that $\mathrm{H}_{2} \mathrm{~S}$ effectively alleviated the senescence and decay in sweetpotato slices and might be developed into a novel fungicide for reduction of black rot or soft rot in sweetpotato.
\end{abstract}

Sweetpotato [Ipomoea batatas (L.) Lam] is grown in regions ranging from the tropics to the subtropics and ranks sixth or seventh among the most important food crops in the world (Scott, 1992). Fleshy storage roots of sweetpotato are used as a staple food and provide vitamin $\mathrm{C}$, provitamin $\mathrm{A}$, vitamin $\mathrm{B}$,

Received for publication 13 Mar. 2014. Accepted for publication 6 May 2014.

Funding for this work was provided by National sweetpotato industrial technology system CARS11-B-02, the Natural Science Foundation of China (31271803, 31301820, 31300133), Open Fund of Key Laboratory of Cell Proliferation and Regulation Biology of Beijing Normal University at Ministry of Education, the Scientific Research Foundation for Returned Overseas Chinese Scholars (SRF for ROCS, SEM), the Natural Science Foundations of Anhui Province (11040606M85), and the Anhui Provincial Education Department (2012AJZR0028, ZD200910).

We gratefully acknowledge the contributions of Russell Jones, University of California at Berkeley, on the revision of the manuscript.

${ }^{1}$ These authors contributed equally to this work.

${ }^{2}$ To whom reprint requests should be addressed; e-mail hzhanglab@gmail.com. and iron and also as a raw material for production of starch, organic acids, and alcoholic beverages (Azhar and Hamdy, 1981; Woolfe, 1992). Sweetpotatoes are usually stored for several months between harvest seasons. As a result of physical damage occurring during harvesting and handling, sweetpotato roots frequently suffer from rapidly developing postharvest diseases, which lead to short-term storage loss (Harrison et al., 2001). Many storage rots are caused by fungi such as Fusarium oxysporum f. sp. batatas, Fusarium solani, Lasiodiplodea theobromae, Rhizopus stolonifer, and Rhizopus nigricans (Harrison et al., 2001; Ray and Ravi, 2005). Microbial infection of sweetpotato roots is manifested by changes in starch, total sugars, organic acids, enzymes, and phytoalexin content (Thompson, 1981). Besides fungal spoilage, respiration, transpiration, and sprouting also lead to loss in weight and alteration of appearance and internal metabolism in sweetpotato roots (Ray and Ravi, 2005). Therefore, the development of effective fungicides is important for controlling spoilage and enhancing storage life of postharvest sweetpotato.
$\mathrm{H}_{2} \mathrm{~S}$, which was regarded as a toxic molecule both to plants and animals, has been recently shown to be a gaseous signaling molecule (Lisjak et al., 2013; Wang, 2012; Zhang et al., 2008). Previous studies showed that $\mathrm{H}_{2} \mathrm{~S}$ can be released by various plant species such as cucumber, squash, pumpkin, and soya bean (Rennenberg, 1983; Wilson et al., 1978). Endogenous $\mathrm{H}_{2} \mathrm{~S}$ generation is catalyzed by sulfite reductase or desulfhydrases (Rausch and Wachter, 2005). Accumulating evidence has demonstrated that $\mathrm{H}_{2} \mathrm{~S}$ can regulate many processes in plants, including seed germination, stomatal movement, root organogenesis, and photosynthesis (GarcíaMata and Lamattina, 2010; Jin et al., 2011, 2013; Lisjak et al., 2013; Zhang et al., 2008, 2009). A senescence-alleviating role of $\mathrm{H}_{2} \mathrm{~S}$ has been found in fresh-cut flowers, strawberry, and kiwifruit (Gao et al., 2013; Hu et al., 2012; Zhang et al., 2011). However, whether $\mathrm{H}_{2} \mathrm{~S}$ can alleviate the senescence and decay in fresh-cut sweetpotato roots and the mechanisms underlying this effect are largely unknown.

Several naturally occurring gases have been shown to have effects as antifungal compounds. Nitric oxide (NO), which like $\mathrm{H}_{2} \mathrm{~S}$ is also a bioactive gaseous signal, exhibits antifungal effects on several postharvest horticulture pathogens, including A. niger, $M$. fructicola, and P. italicum (Lazar et al., 2008). $\mathrm{H}_{2} \mathrm{~S}$ has been shown to be released on pathogen attack in several plant species (Bloem et al., 2004), suggesting a possible endogenous role of $\mathrm{H}_{2} \mathrm{~S}$ in fungal inhibition. Additionally, inorganic and organic sulfur compounds have long being used as fungicides. Thus, in the present study, we aim to study the effect of $\mathrm{H}_{2} \mathrm{~S}$ on the growth of horticultural pathogens and physiological changes in sweetpotato slices.

\section{Materials and Methods}

Plant materials and treatments. Sweetpotato (Ipomoea batatas L., cv. Xushu 18) was supplied by the National Sweet Potato Improvement Center, Xuzhou, Jiangsu Province, China. Sweetpotato tubers, without physical damage and microbial infection, were washed in flowing tap water and then cut into slices of $1 \mathrm{~cm} \times 1 \mathrm{~cm} \times 7 \mathrm{~cm}$. NaHS (Sigma, St. Louis, MO) was used as a $\mathrm{H}_{2} \mathrm{~S}$ donor. Aqueous NaHS solutions $(150 \mathrm{~mL})$ of $0,0.5,1.0,1.5,2.0$, and $2.5 \mathrm{mmol} \cdot \mathrm{L}^{-1}$ were prepared in sealed containers (volume $3 \mathrm{~L}$ ). These solutions could release $\mathrm{H}_{2} \mathrm{~S}$ gas rapidly, reaching a stable level of $\mathrm{H}_{2} \mathrm{~S}$ concentration within $30 \mathrm{~min}$. Approximately 11 sweetpotato slices were placed on a plate with pores. The plate was located in the middle part of the container, the bottom of which was water or NaHS solution. This method allows the sweetpotato slices to be fumigated by $\mathrm{H}_{2} \mathrm{~S}$ released from NaHS solution instead of being immersed in solutions. Incubation temperature was $20 \pm 0.5^{\circ} \mathrm{C}$ at a relative humidity of $85 \%$ to $90 \%$. NaHS solutions were renewed daily and the sweetpotato slices were observed every $24 \mathrm{~h}$ for $4 \mathrm{~d}$. For physiological 
parameters, sweetpotato slices were sampled until $6 \mathrm{~d}$. Three containers were used for a single experiment. This work was repeated three times with similar results.

Sensory evaluation of sweetpotato samples. Sensory evaluation of sweetpotato samples was conducted by a panel of 10 experts. Before the test, the expert was trained to recognize and score tissue quality. A 9-point hedonic scale, where $9=$ like extremely, $7=$ like moderately, $5=$ neither like nor dislike, $3=$ dislike moderately, and 1 = dislike extremely, was used for the evaluation (Meilgaard et al., 1991).

Determination of reducing sugar concentration. Reducing sugar content was measured according to the method of Miller (1959). Samples (5.00 $\pm 0.05 \mathrm{~g})$ of sweetpotato slices until $6 \mathrm{~d}$ of storage were ground in $5 \mathrm{~mL}$ phosphate buffer ( $\left.\mathrm{pH} 7.0,200 \mathrm{mmol} \cdot \mathrm{L}^{-1}\right)$. The homogenate was centrifuged at $10,000 \mathrm{~g}$ for $30 \mathrm{~min}$, and the supernatant was used for reducing sugar determination. The supernatant $(0.2 \mathrm{~mL})$ was mixed with $1.5 \mathrm{~mL} 3$, 5-dinitrosalicylic acid and $1.8 \mathrm{~mL}$ distilled water. The mixture was heated at $100{ }^{\circ} \mathrm{C}$ for $5 \mathrm{~min}$, cooled on ice, and $25 \mathrm{~mL}$ distilled water added. Reducing sugar was determined spectrophotometrically at $540 \mathrm{~nm}$ and the results are expressed as milligrams per gram fresh weight (FW).

Determination of guaiacol peroxidase, polyphenol oxidase, lipoxygenase activities, and malondialdehyde. Activities of POD and LOX were determined by procedures described by Zhang et al. (2008). Sweetpotato samples $(5.00 \pm 0.05 \mathrm{~g})$ in up to $6 \mathrm{~d}$ of storage were homogenized in $1 \mathrm{~mL}$ of $200 \mathrm{mmol} \cdot \mathrm{L}^{-1}$ ice-cold phosphate buffer ( $\mathrm{pH}$ 7.8) containing $1.0 \mathrm{mmol} \cdot \mathrm{L}^{-1}$ ethylene diamine tetra acetic acid. The homogenate was centrifuged at $12,000 \mathrm{~g}$ at $4{ }^{\circ} \mathrm{C}$ for $20 \mathrm{~min}$, and the supernatant was used for activity measurement. Analysis of POD activity was based on the oxidation of guaiacol by hydrogen peroxide. The reaction mixture contained $2.6 \mathrm{~mL}$ of $50 \mathrm{mmol} \cdot \mathrm{L}^{-1}$ phosphate buffer ( $\mathrm{pH} 6.1$ ), $1 \mathrm{~mL}$ of $3 \%$ $\mathrm{H}_{2} \mathrm{O}_{2}, 1 \mathrm{~mL}$ of $1 \%$ guaiacol, and 100 to $200 \mu \mathrm{L}$ of enzyme extract. The increase in absorbance at $420 \mathrm{~nm}$ was recorded. One unit of POD activity was defined as an increase or decrease of 0.01 in absorbance per minute. The values of POD activities are indicated as units per gram $\mathrm{FW}$.

For LOX, samples $(5.00 \pm 0.05 \mathrm{~g})$ of sweetpotato slices in up to $6 \mathrm{~d}$ of storage were homogenized in $1 \mathrm{~mL}$ of $200 \mathrm{mmol} \cdot \mathrm{L}^{-1}$ phosphate buffer ( $\mathrm{pH}$ 6.0). The homogenate was centrifuged at $15,000 \mathrm{~g}$ at $4{ }^{\circ} \mathrm{C}$ for $10 \mathrm{~min}$, and the supernatant was used for LOX activity assay. The assay mixture in a total volume of $3 \mathrm{~mL}$ contained $200 \mathrm{mmol} \cdot \mathrm{L}^{-1}$ borate buffer $(\mathrm{pH} 6.0), 0.25 \%$ linoleic acid, $0.25 \%$ Tween- 20 , and $50 \mu \mathrm{L}$ of enzyme extract. The reaction was carried out at $25{ }^{\circ} \mathrm{C}$ for $3 \mathrm{~min}$, and the activity of LOX was determined in the presence of linoleic acid by monitoring the changes in absorbance at $234 \mathrm{~nm}$.

Activity of PPO was determined by procedures described by Benjamin and Montgomery (1973). Samples $(2.00 \pm 0.05 \mathrm{~g})$ of sweetpotato slices in $6 \mathrm{~d}$ of storage were homogenized in $5 \mathrm{~mL}$ of sodium phosphate buffer (50 mmol. $\left.\mathrm{L}^{-1}, \mathrm{pH} 7.2\right)$. The homogenate was centrifuged at $5000 \mathrm{~g}$ at $4{ }^{\circ} \mathrm{C}$ for $15 \mathrm{~min}$, and the supernatant was used for the activity assay with catechol as substrate. One unit of PPO activity was defined as an increase of 0.01 O.D. value in absorbance at $410 \mathrm{~nm}$ per minute. The results were expressed as $\mathrm{U} \cdot \mathrm{g}^{-1} \mathrm{FW}$. Each experiment was repeated three times.

Contents of MDA were determined according to the methods of Zhang et al. (2010). Samples $(5.00 \pm 0.05 \mathrm{~g})$ of sweetpotato slices were ground in $3 \mathrm{~mL}$ of $0.1 \%$ trichloroacetic acid (TCA) and centrifuged at $15,000 \mathrm{~g}$ for $10 \mathrm{~min}$, and $0.5 \mathrm{~mL}$ of the supernatant was mixed with $2 \mathrm{~mL}$ of $20 \%$ TCA containing $0.5 \%$ thiobarbituric acid. The mixture was heated at $90{ }^{\circ} \mathrm{C}$ for $20 \mathrm{~min}$, cooled on ice, and centrifuged at $10,000 \mathrm{~g}$ for $5 \mathrm{~min}$. Absorbance was recorded at $532 \mathrm{~nm}$ and the value for nonspecific absorption at $600 \mathrm{~nm}$ was subtracted. An extinction coefficient of $155 \mathrm{~mm}^{-1} \cdot \mathrm{cm}^{-1}$ was used to calculate MDA content.

Fungi isolation from sweetpotato and $\mathrm{H}_{2} \mathrm{~S}$ treatment of fungi. $R$. nigricans, $M$. rouxianus, and $G$. candidum were isolated from the surface of sweetpotato showing soft rot and black rot lesions and cultured on agar rose bengal medium at $28{ }^{\circ} \mathrm{C}$ in the dark. Spore suspensions were prepared by flooding 6 -dold sporulating cultures with sterile distilled water. The spore concentrations of the pathogen were determined with a hemacytometer and diluted with sterile distilled water to $1 \times$ $10^{4}$ spores $/ \mathrm{mL}$. Aliquots of spore suspension $(2 \mu \mathrm{L})$ were placed on $9-\mathrm{cm}$ diameter petri dishes maintained in sealed 3 -L containers. NaHS solutions at $150 \mathrm{~mL}$ in concentrations of $0,0.5,1.0,1.5,2.0$, and $2.5 \mathrm{mmol} \cdot \mathrm{L}^{-1}$ were placed in the bottom of the sealed containers at $20{ }^{\circ} \mathrm{C}$ with a relative humidity of $90 \%$ to $95 \%$ to fumigate fungi for the time indicated in the figure legends. For fungal infection of sweetpotato roots, roots were cut into slices of $5 \mathrm{~cm} \times$ $5 \mathrm{~cm} \times 1 \mathrm{~cm}$. Spore suspension at $5 \mu \mathrm{L}$ of $1 \times$
$10^{4}$ spores $\cdot \mathrm{mL}^{-1}$ of $R$. nigricans, $M$. rouxianus, or $G$. candidum were inoculated onto the sweetpotato slices with 20 inoculations on a slice (Zheng et al., 2007). After inoculation, slices were stored at $20{ }^{\circ} \mathrm{C}$ in 3 -L sealed containers with $150 \mathrm{~mL}$ of $0,0.5,1.0,1.5,2.0$, or $2.5 \mathrm{mmol} \cdot \mathrm{L}^{-1} \mathrm{NaHS}$ on the bottom for $5 \mathrm{~d}$. The number of infected inoculations and the lesion diameters were examined on Day 5. Inoculation with infection diameter above $2 \mathrm{~mm}$ was defined as infected and those below $2 \mathrm{~mm}$ as the uninfected. The infection percentage was calculated from 100 inoculations. Each experiment was repeated three times.

Measurement of endogenous $\mathrm{H}_{2} \mathrm{~S}$ in sweetpotato. Hydrogen sulfide was determined by formation of methylene blue from dimethylp-phenylenediamine in $\mathrm{H}_{2} \mathrm{SO}_{4}$ according to the method described by Sekiya et al. (1982).

Statistics. Data were analyzed by one-way analysis of variance, and the results are expressed as the mean values \pm SD of three independent experiments. Fisher's least significant differences were calculated following a significant $(P<0.01$ or $P<0.05)$ test. The symbols * and $* *$ in the figures stand for a significant difference between treatments at $P<0.05$ and $P<0.01$, respectively.

\section{Results}

$\mathrm{H}_{2} \mathrm{~S}$ alleviates the decay of fresh-cut sweetpotato roots. In this work, fresh-cut sweetpotato slices were fumigated with $\mathrm{H}_{2} \mathrm{~S}$ released from NaHS solutions $(0,0.5,1.0$, $1.5,2.0$, or $\left.2.5 \mathrm{mmol} \cdot \mathrm{L}^{-1}\right)$. As shown in Figure 1 and sensory evaluation in Table 1, $\mathrm{H}_{2} \mathrm{~S}$ fumigation effectively alleviated the decay of fresh-cut sweetpotato tissue and showed a higher score of sensory evaluation in a dose-dependent manner. After $3 \mathrm{~d}$ of storage, sweetpotato slices from water controls rotted quickly with obvious fungal growth, whereas $\mathrm{H}_{2} \mathrm{~S}$ treatment alleviated fungal growth and browning of the surface. A concentration of $2 \mathrm{mmol} \cdot \mathrm{L}^{-1} \mathrm{NaHS}$ was found to be the most effective, whereas higher concentrations conferred no further effect on the
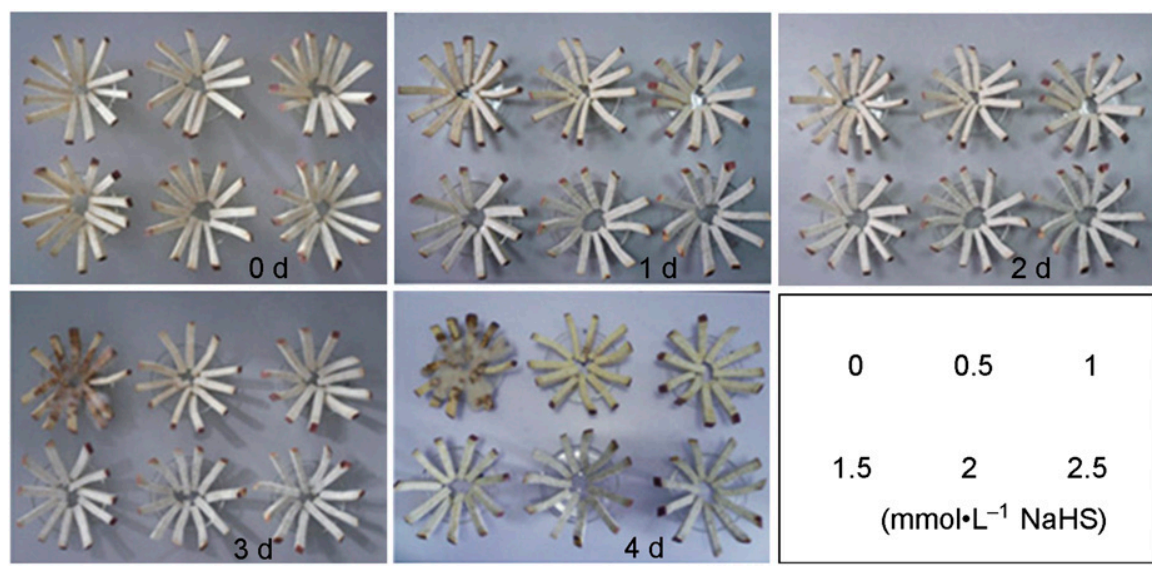

Fig. 1. Effect of hydrogen sulfide $\left(\mathrm{H}_{2} \mathrm{~S}\right)$ on senescence and decay of fresh-cut sweetpotato slices. Fresh-cut slices were fumigated with $\mathrm{H}_{2} \mathrm{~S}$ gas released from different concentrations $(0,0.5,1.0,1.5,2.0$, $2.5 \mathrm{mmol} \cdot \mathrm{L}^{-1}$ ) of sodium hydrosulfide (NaHS) solutions and photographed from Day 0 to Day 4. The experimental treatment concentrations are shown in the lower right part. 
senescence of sweetpotato compared with the optimal $2 \mathrm{mmol} \cdot \mathrm{L}^{-1}$.

Effect of $\mathrm{H}_{2} \mathrm{~S}$ on the content of reducing sugar in sweetpotato. To study the nutrient level in sweetpotato, we determined the level of reducing sugar in sweetpotato under $\mathrm{H}_{2} \mathrm{~S}$ fumigation. Figure 2 showed that $\mathrm{H}_{2} \mathrm{~S}$ maintained significantly higher levels of reducing sugar than water control during storage. In the early stage of storage ( 0 to $3 \mathrm{~d}$ ), reducing sugar content in water control decreased steadily but thereafter increased slightly. A similar pattern of change in reducing sugar content was observed in $\mathrm{H}_{2} \mathrm{~S}$-treated sweetpotato slices, and the levels were always higher than those of water control.

Effect of $\mathrm{H}_{2} \mathrm{~S}$ on the activities of $P O D$, PPO, LOX, and the content of MDA in sweetpotato. We studied changes in senescence related enzymes such as POD, PPO, and LOX and the lipid peroxidation marker MDA content in sweetpotato under $\mathrm{H}_{2} \mathrm{~S}$ treatment. The overall change pattern of POD activity was similar in the water control and $\mathrm{H}_{2} \mathrm{~S}$ treatment (Fig. 3A). During the first $3 \mathrm{~d}$ of storage, POD activity increased steadily and then decreased gradually in both of water control and $\mathrm{H}_{2} \mathrm{~S}$ treatment. However, $\mathrm{H}_{2} \mathrm{~S}$ treatment maintained a significantly higher level of POD activity compared with the water control.

PPO, which participates in the oxidation of phenolics into brown-colored pigments
(Mishra et al., 2013), was also examined in sweetpotato slices (Fig. 3B). PPO activities in water controls increased gradually up to Day 4 of storage and then maintained relatively a stable level. In contrast, PPO activities in $\mathrm{H}_{2} \mathrm{~S}$-treated sweetpotato tissue decreased dramatically during the first $3 \mathrm{~d}$ and then sustained a stable level from 3 to $6 \mathrm{~d}$ of storage. During Day 3 to Day 6, PPO activity in water controls was $\approx 2$-fold of that in $\mathrm{H}_{2} \mathrm{~S}$ treatment, suggesting that $\mathrm{H}_{2} \mathrm{~S}$ maintained a lower level of PPO activity.

The effect of $\mathrm{H}_{2} \mathrm{~S}$ treatment on the changes of LOX activity in sweetpotato slices is shown in Figure 3C. LOX activity in water controls increased dramatically during the first $3 \mathrm{~d}$ of storage and then decreased rapidly until the end of storage. In comparison with the water control, LOX activity increased slightly and peaked to $\approx 30 \mathrm{U} \cdot \mathrm{g}^{-1}$ FW on Day 3 and then decreased gradually. During the entire storage time, $\mathrm{H}_{2} \mathrm{~S}$ was found to maintain a lower level of LOX activity in sweetpotato slices.

As shown in Figure 3D, there was a rapid accumulation of MDA during the first $3 \mathrm{~d}$ of storage in water controls followed by a decrease on Day 4 to a level that remained stable level until the end of the storage period. As for $\mathrm{H}_{2} \mathrm{~S}$ treatment, MDA content increased during the first $2 \mathrm{~d}$ of storage and then fluctuated at a lower level compared with water controls.

Table 1. Sensory scores of sweetpotato slices treated with different concentrations of sodium hydrosulfide (NaHS) and control (water) during storage at $20 \pm 0.5^{\circ} \mathrm{C} .{ }^{z}$

\begin{tabular}{lccccc}
\hline & \multicolumn{5}{c}{ Storage time (day) } \\
\cline { 2 - 6 } Overall quality & 0 & 1 & 2 & 3 & 4 \\
\hline Water control & $9 \pm 0 \mathrm{a}$ & $6.8 \pm 0.55 \mathrm{bc}$ & $5.8 \pm 0.12 \mathrm{c}$ & $3 \pm 0.35 \mathrm{e}$ & $1.4 \pm 0.27 \mathrm{f}$ \\
$0.5 \mathrm{mmol} \cdot \mathrm{L}^{-1} \mathrm{NaHS}$ & $9 \pm 0 \mathrm{a}$ & $7.6 \pm 0.27 \mathrm{bc}$ & $6.4 \pm 0.27 \mathrm{c}$ & $4.6 \pm 0.27 \mathrm{~d}$ & $3.9 \pm 0.11 \mathrm{e}$ \\
$1 \mathrm{mmol} \cdot \mathrm{L}^{-1} \mathrm{NaHS}$ & $9 \pm 0 \mathrm{a}$ & $7.9 \pm 0.11 \mathrm{~b}$ & $6.5 \pm 0.25 \mathrm{c}$ & $6.1 \pm 0.27 \mathrm{c}$ & $4.5 \pm 0.25 \mathrm{de}$ \\
$1.5 \mathrm{mmol} \cdot \mathrm{L}^{-1} \mathrm{NaHS}$ & $9 \pm 0 \mathrm{a}$ & $7.9 \pm 0.37 \mathrm{~b}$ & $7.3 \pm 0.22 \mathrm{bc}$ & $6.7 \pm 0.22 \mathrm{c}$ & $5.7 \pm 0.22 \mathrm{c}$ \\
$2 \mathrm{mmol} \cdot \mathrm{L}^{-1} \mathrm{NaHS}$ & $9 \pm 0 \mathrm{a}$ & $8.1 \pm 0.27 \mathrm{~b}$ & $7.5 \pm 0.25 \mathrm{bc}$ & $7 \pm 0.27 \mathrm{bc}$ & $6.1 \pm 0.27 \mathrm{c}$ \\
$2.5 \mathrm{mmol} \cdot \mathrm{L}^{-1} \mathrm{NaHS}$ & $9 \pm 0 \mathrm{a}$ & $7.9 \pm 0.37 \mathrm{~b}$ & $7.3 \pm 0.22 \mathrm{bc}$ & $6.9 \pm 0.37 \mathrm{bc}$ & $5.9 \pm 0.11 \mathrm{c}$ \\
\hline
\end{tabular}

${ }^{\mathrm{z}}$ Data are presented as means $\pm \mathrm{SD}(\mathrm{n}=10)$. Different letters indicate significant differences $(P<0.05)$ between the treatments.

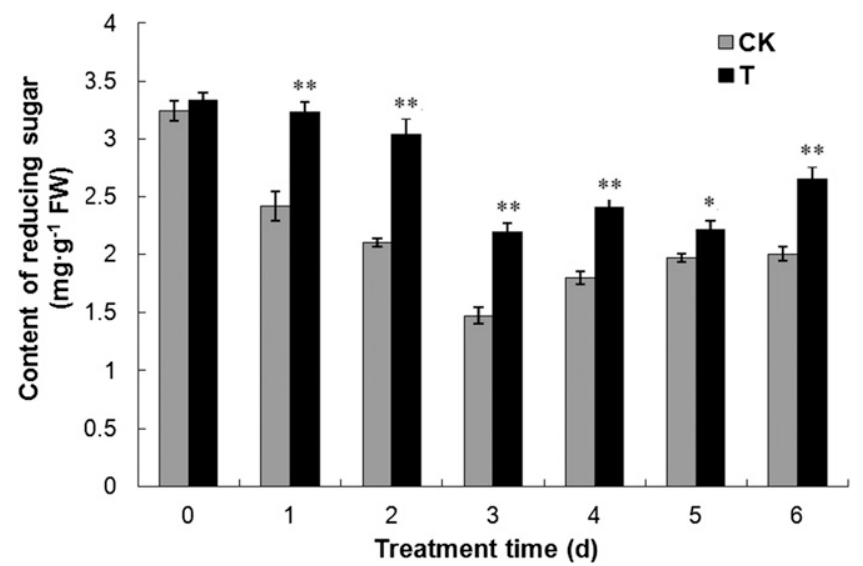

Fig. 2. Effect of hydrogen sulfide $\left(\mathrm{H}_{2} \mathrm{~S}\right)$ on the accumulation of reducing sugar in fresh-cut sweetpotato. Fresh-cut sweetpotato was fumigated with $2 \mathrm{mmol} \cdot \mathrm{L}^{-1}$ sodium hydrosulfide (NaHS) aqueous solution (T) with water as a control (CK) for 0 to $6 \mathrm{~d}$. Data are presented as means $\pm \mathrm{SD}(\mathrm{n}=3)$. The symbols * and ** in this figure and following ones stand for significant difference between $\mathrm{CK}$ (water) and $\mathrm{T}\left(\mathrm{H}_{2} \mathrm{~S}\right.$ fumigation) at $P<0.05$ and $P<0.01$, respectively.

Inhibitory effect of $\mathrm{H}_{2} \mathrm{~S}$ on fungi isolated from fresh-cut sweetpotato slices. The reduced fungal growth in $\mathrm{H}_{2} \mathrm{~S}$-fumigated sweetpotato slices directed us to study the effect of $\mathrm{H}_{2} \mathrm{~S}$ on fungal growth. Three fungi, $R$. nigricans, M. rouxianus, and G. candidum, were isolated from the surface of sweetpotato infected with soft rot and black rot. As shown in Figure 4, the fungi were subjected to different concentrations of $\mathrm{NaHS}(0,0.5$, $\left.1.0,1.5,2.0,2.5 \mathrm{mmol} \cdot \mathrm{L}^{-1}\right)$. With increased concentrations of $\mathrm{NaHS}$, fungal growth was inhibited gradually. As observed in the lower part of Figure $4 \mathrm{~A}-\mathrm{C}$, the colony diameters of the three pathogens were severely decreased under $2 \mathrm{mmol} \cdot \mathrm{L}^{-1} \mathrm{NaHS}$ fumigation, suggesting the effective fungicide role of $\mathrm{H}_{2} \mathrm{~S}$. The effects of $\mathrm{H}_{2} \mathrm{~S}$ fumigation on fungal infection of sweet slices are shown in Figure 5. At $2 \mathrm{mmol} \cdot \mathrm{L}^{-1} \mathrm{NaHS}$, the percentage fungal infection was decreased sharply for all three pathogens tested further suggesting an effective fungicidal role of $\mathrm{H}_{2} \mathrm{~S}$.

\section{Discussion}

Sweetpotato roots are commonly subjected to postharvest spoilage as a result of mechanical injury, sprouting, pests, and especially fungal diseases (Ray and Ravi, 2005). Several fungi have been shown to induce spoilage in sweetpotatoes such as Fusarium spp., L. theobromae, R. stolonifer, and $R$. nigricans (Harrison et al., 2001; Ray and Ravi, 2005). Accordingly, considerable research effort has focused on developing new fungicides to control horticulture pathogens. Sulfur compounds have been widely used as fungicides from the time of antiquity. Marsh (1929) reported that $\mathrm{H}_{2} \mathrm{~S}$ was toxic to germinating fungal spores and Haneklaus et al. (2007) calculated that a minimum uptake of $10 \mu \mathrm{M} \mathrm{H}_{2} \mathrm{~S} / \mathrm{h}$ by pathogens could generate a fungicidal effect. In the present study, we found that $\mathrm{H}_{2} \mathrm{~S}$ treatment alleviated the senescence and fungal decay in fresh-cut sweetpotato slices (Fig. 1). Three fungal pathogens, $R$. nigricans, M. rouxianus, and G. candidum, were isolated from sweetpotato having black rot or soft rot. Concentrations of NaHS from 0.5 to $2.5 \mathrm{mmol} \cdot \mathrm{L}^{-1}$ inhibited growth of these three fungal pathogens on petri dishes in a dose-dependent manner. When the three pathogens were inoculated on the cut surface of sweetpotato slices, $2 \mathrm{mmol} \cdot \mathrm{L}^{-1} \mathrm{NaHS}$ effectively reduced fungal infection (Fig. 5). These antifungal effects suggest the potential use of $\mathrm{H}_{2} \mathrm{~S}$ as a natural fungicide to inhibit microbial spoilage on sweetpotato roots.

Fungal spoilage of sweetpotato roots is associated with a decrease in starch, total sugar, and organic acid contents (Ray and Ravi, 2005). In the present study, $\mathrm{H}_{2} \mathrm{~S}$ treatment was found to maintain a higher level of reducing sugar than water control (Fig. 2), suggesting the protective role of $\mathrm{H}_{2} \mathrm{~S}$ in postharvest storage of sweetpotato. In response to wounding, peeling, or fungal spoilage of sweetpotato, many enzymes are induced such as those in the phenyl propanoid pathway, i.e., phenylanaline ammonia lyase and transcinnamic acid 
A
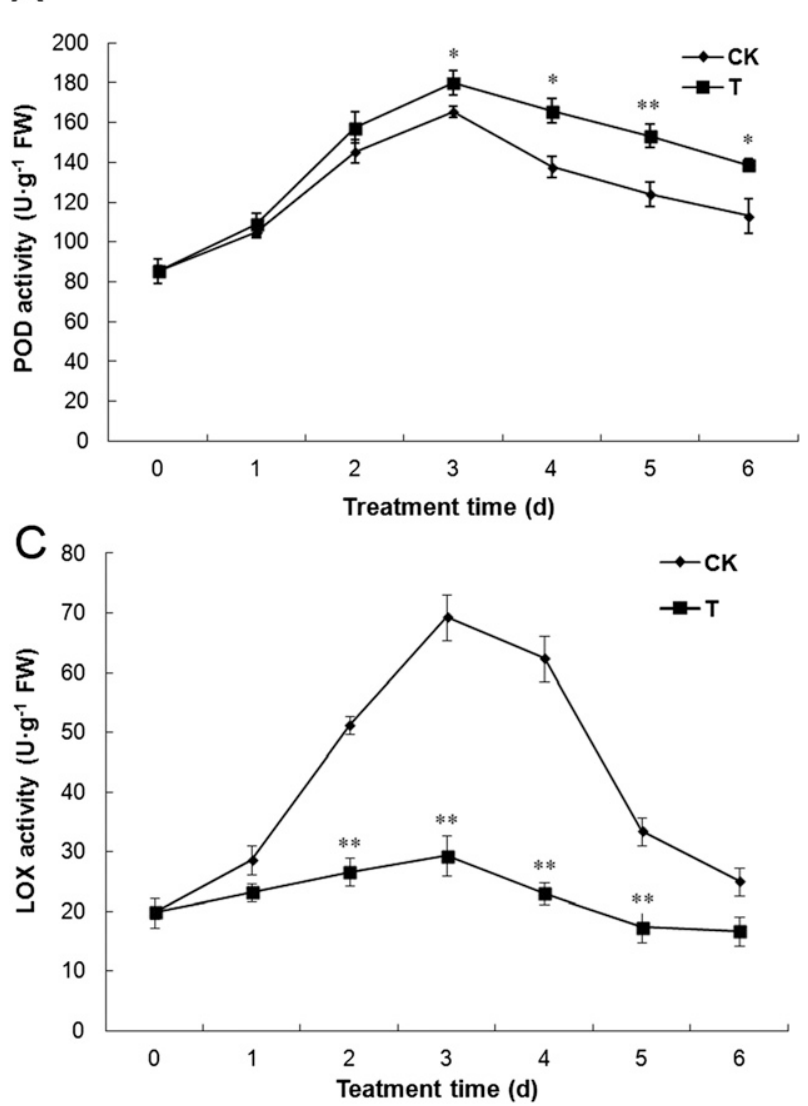

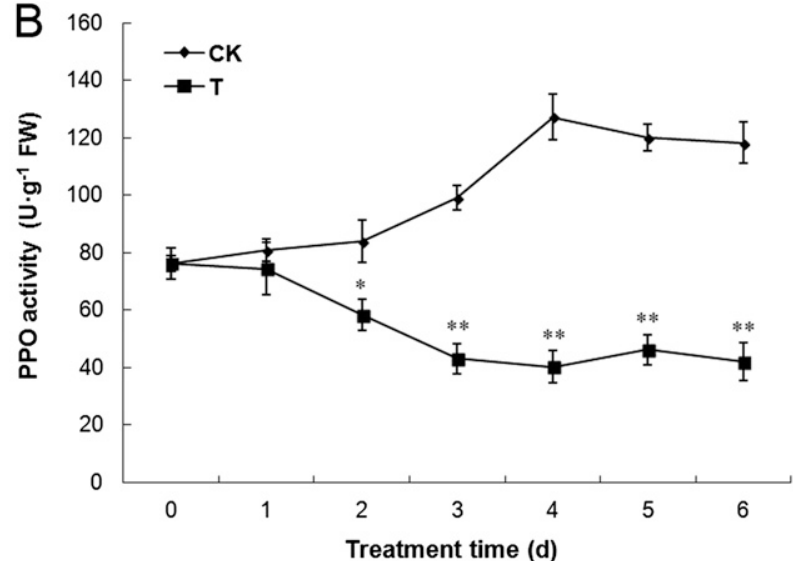

D

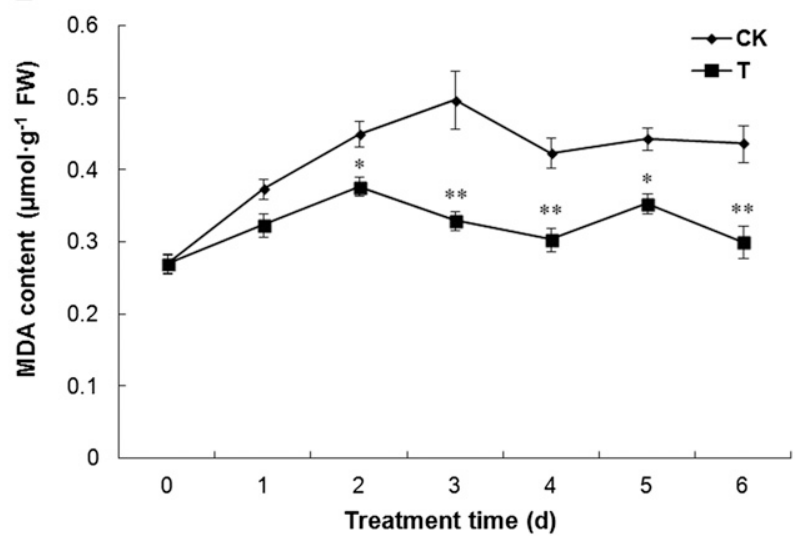

Fig. 3. Role of hydrogen sulfide $\left(\mathrm{H}_{2} \mathrm{~S}\right)$ in the regulation of the activities of guaiacol peroxidase (POD) (A), polyphenol oxidase (PPO) (B), lipoxygenase (LOX) (C), and the content of malondialdehyde (MDA) (D) in fresh-cut sweetpotato. Fresh-cut sweetpotato were fumigated with $2 \mathrm{mmol} \cdot \mathrm{L}^{-1}$ sodium hydrosulfide (NaHS) aqueous solution (T) with water as the control $(\mathrm{CK})$ for 0 to $6 \mathrm{~d}$. Data are presented as means $\pm \mathrm{SD}(\mathrm{n}=3)$.

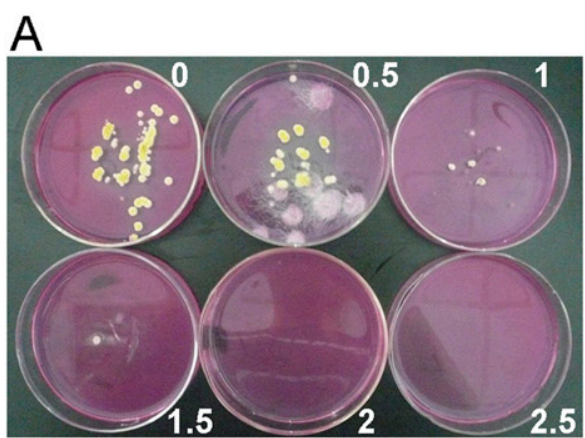

Rhizopus nigricans

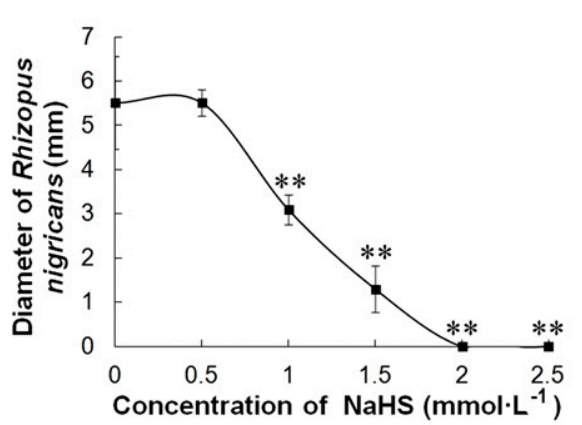

B

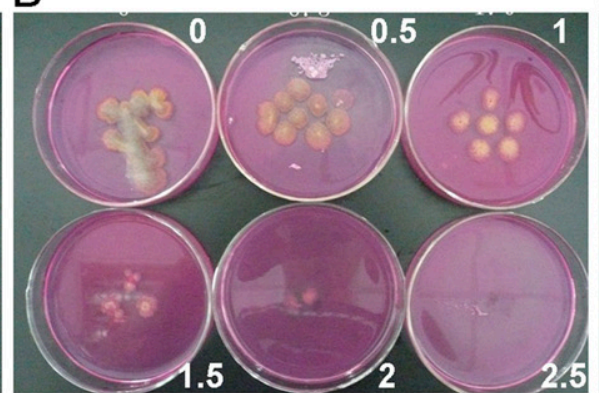

Mucor rouxianus

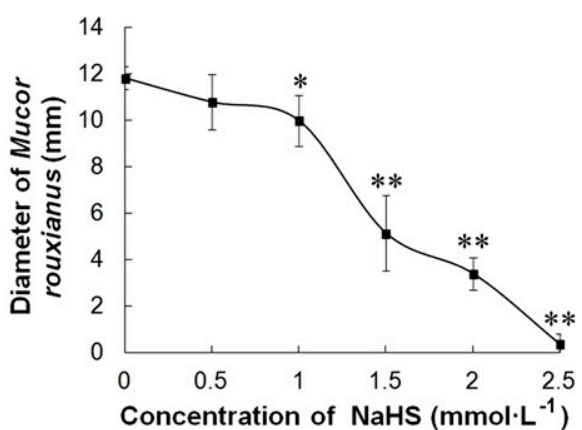

C

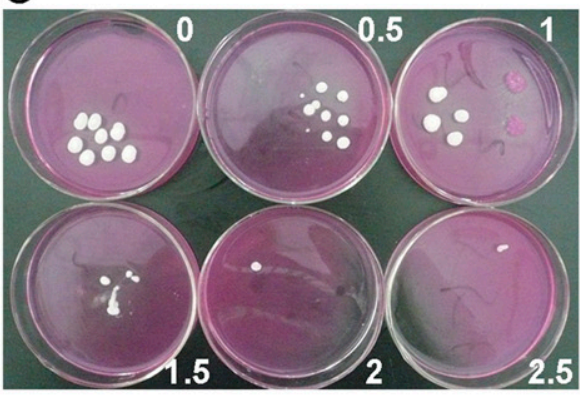

Geotrichum candidum

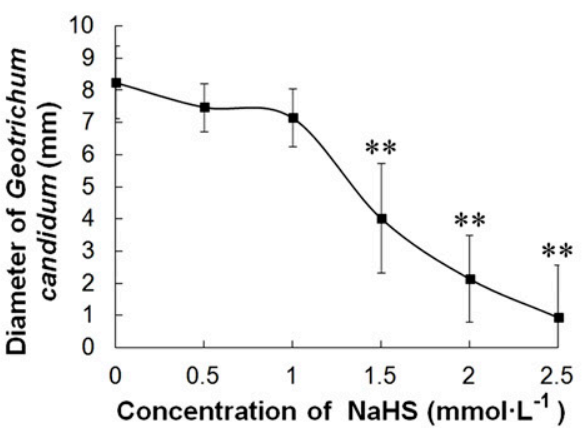

Fig. 4. Inhibitory effect of hydrogen sulfide $\left(\mathrm{H}_{2} \mathrm{~S}\right)$ on the growth of pathogenic fungi isolated from sweetpotato, $R$. nigricans (A), M. rouxianus (B), and G. candidum $(\mathbf{C})$. The upper photographs in the figure indicate the growth of the fungi on medium subjected to different concentrations from left to right, upper to lower $0,0.5,1.0,1.5,2.0$, and $2.5 \mathrm{mmol} \cdot \mathrm{L}^{-1}$ sodium hydrosulfide (NaHS) for $5 \mathrm{~d}$, and the lower part of the figure shows the diameters of fungal colonies. 

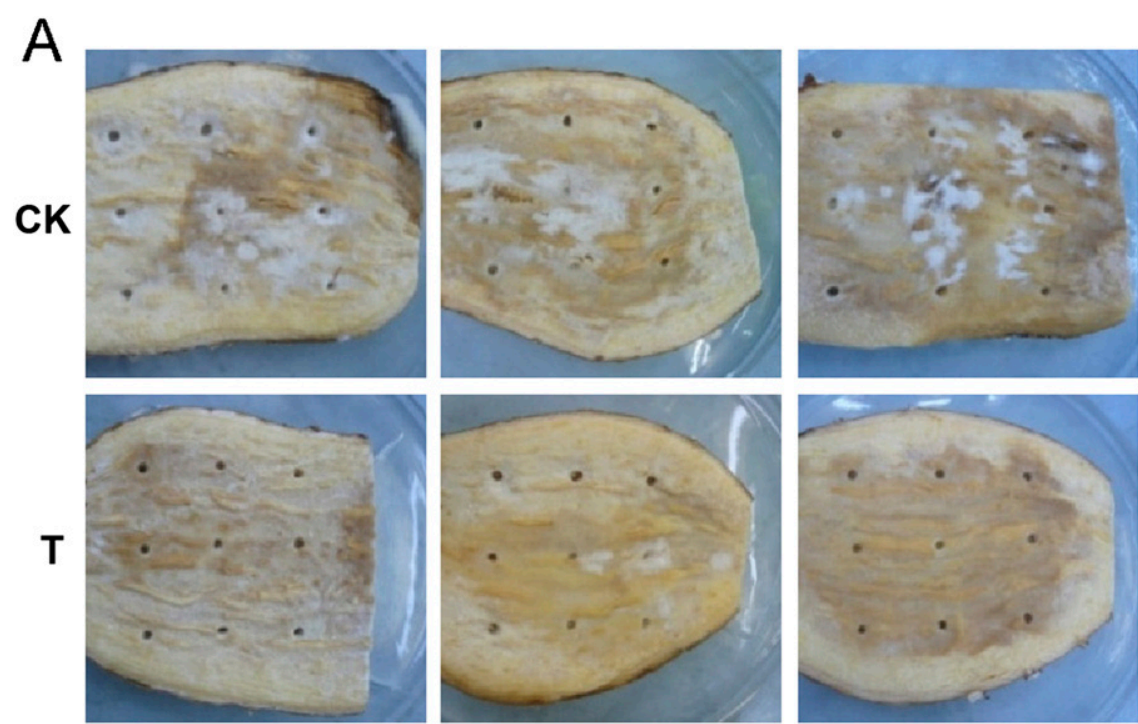

R. nigricans

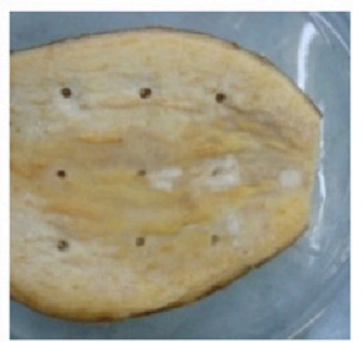

M. rouxianus

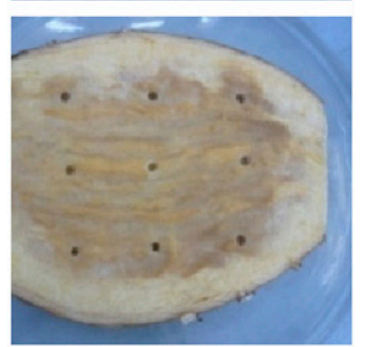

G. candidum

B

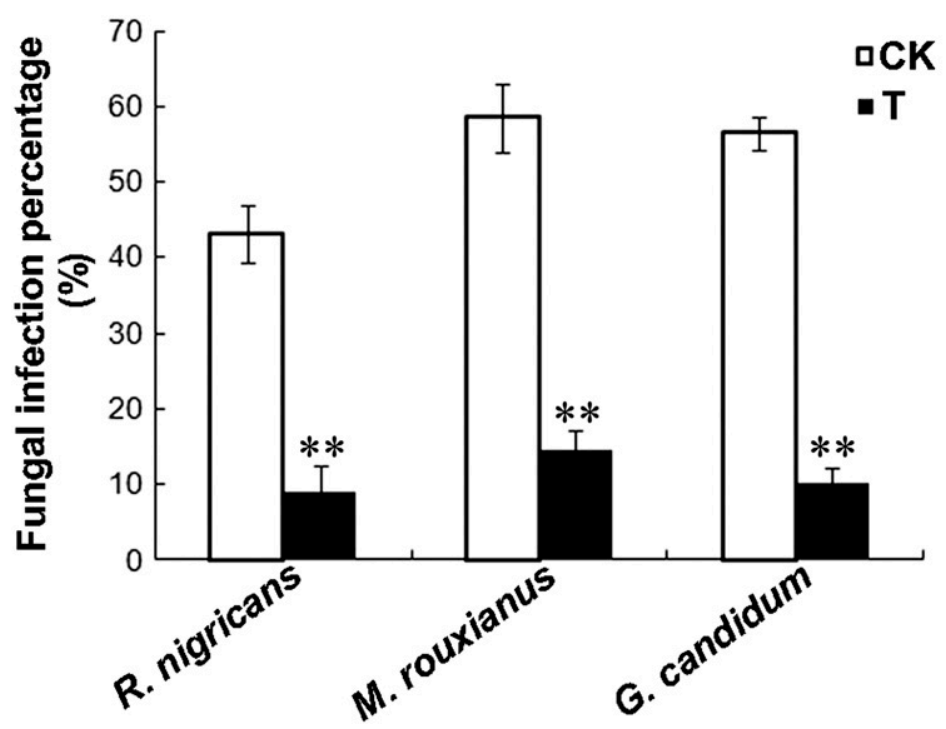

Fig. 5. Effect of hydrogen sulfide $\left(\mathrm{H}_{2} \mathrm{~S}\right)$ on the infection of sweetpotato root tissue by pathogenic fungi. Spore suspension of $R$. nigricans, $M$. rouxianus, or $G$. candidum was inoculated onto the surface of the sweetpotato roots that were then fumigated with $2 \mathrm{mmol} \cdot \mathrm{L}^{-1}$ sodium hydrosulfide (NaHS) solution (T) or water $(\mathrm{CK})$ in a 3 -L sealed container for $5 \mathrm{~d}$ and photographed $(\mathbf{A})$. The infection percentage was calculated from 100 inoculations $(\mathbf{B})$. Each experiment was repeated three times.

4-hydroxylase (Tanaka and Uritani, 1977; Uritani, 1998; Yin et al., 2012). Besides, fresh-cut results in a severe wounding response, including oxidative browning, tissue softening, water loss, and production of undesirable flavors and odors (Martín-Belloso et al., 2007). In infected sweetpotato tissue, POD and PPO activities are increased (Arinze and Smith, 1982). When treated with $\mathrm{H}_{2} \mathrm{~S}$, the activities of POD are enhanced in sweetpotato slices (Fig. 3A), whereas the activities of catalase, ascorbate peroxidase, and superoxide dismutase are not significantly different between $\mathrm{H}_{2} \mathrm{~S}$ treatment and controls. $\mathrm{POD}$, which is an effective antioxidant enzyme, may help to scavenge reactive oxygen species generated during postharvest senescence of fruits and vegetables ( $\mathrm{Hu}$ et al., 2012; Reyes et al., 2007; Zhang et al., 2011).
Consistent with a previous report (Arinze and Smith, 1982), we observed an increase in the activity of PPO in water controls during sweetpotato storage (Fig. 3B), which might be a response to fungal growth. Meanwhile, $\mathrm{H}_{2} \mathrm{~S}$ maintained PPO activity at a low level for the duration of storage (Fig. 3B). PPO is commonly induced during fruit injury, fungal infection, and senescence (Arinze and Smith, 1982). Thus, we propose $\mathrm{H}_{2} \mathrm{~S}$ indirectly inhibited PPO activity by reducing fungal infection and alleviating senescence in sweetpotatoes.

The senescence of fresh-cut fruit or vegetables is accompanied by lipid peroxidation. Increased LOX activity is found to be associated with enhanced lipid peroxidation in plants (Hodges and Toivonen, 2008). LOX catalyze the oxygenation of polyunsaturated fatty acids into lipid hydroperoxides and lead to the formation of hydroperoxides (Duan et al., 2007). MDA, a secondary end product of polyunsaturated fatty acid oxidation, is an index of lipid peroxidation (Lana and Tijskens, 2006). In our work on sweetpotato senescence, there was an increase in LOX activity and MDA content. During the first $3 \mathrm{~d}$ of storage, $\mathrm{H}_{2} \mathrm{~S}$ treatment reduced the activities of LOX and a concomitant lowering of MDA content was observed (Fig. 3C-D). We propose that $\mathrm{H}_{2} \mathrm{~S}$ alleviated lipid peroxidation by activating the antioxidant enzyme POD and attenuating LOX activity, thereby delaying postharvest senescence in sweetpotato.

NO used to be regarded as a toxic gas but has now been found to act as a signaling molecule in plants and is extensively studied in postharvest storage of fruits and vegetables (Leshem et al., 1998; Wills et al., 2000). For instance, NO treatment was able to protect wounded sweetpotato roots from an increase in MDA, $\mathrm{H}_{2} \mathrm{O}_{2}$, and $\mathrm{O}_{2}{ }^{-}$by activating antioxidant enzymes (Yin et al., 2012). Considering the successful use of NO in postharvest storage, we propose that low concentrations of $\mathrm{H}_{2} \mathrm{~S}$ could also be used to alleviate postharvest senescence and decay. In this study, the application concentration of NaHS solution at 0.5 to $2.5 \mathrm{mmol} \cdot \mathrm{L}^{-1}$ releases $\approx 0.005$ to $0.01 \mathrm{ppm} \mathrm{H}_{2} \mathrm{~S}$ gas in a sealed container, sufficient to act as an effective fumigant during sweetpotato storage (Hu et al., 2012). As stated in the patent, "A process of food preservation with hydrogen sulfide, WO2013106277 A1," $0.0047 \mathrm{ppm}$ is the recognition threshold and $10 \mathrm{ppm}$ has an exposure limit of $8 \mathrm{~h} \cdot \mathrm{d}^{-1}$, suggesting NaHS concentrations that we used are relatively safe. In our previous work, we showed that $\mathrm{H}_{2} \mathrm{~S}$ treatment induced an increase in endogenous $\mathrm{H}_{2} \mathrm{~S}$ levels in strawberry by $10 \%$ to $20 \%$ compared with that of the water control (Hu et al., 2012). Thus, we propose that fumigation with trace $\mathrm{H}_{2} \mathrm{~S}$ gas released from NaHS solution on sweetpotato could be safe and practical.

In conclusion, our results indicate that $\mathrm{H}_{2} \mathrm{~S}$ inhibits fungal growth and modulates senescence-related enzymes in treated sweetpotato tissue, thereby alleviating postharvest fungal spoilage and senescence.

\section{Literature Cited}

Arinze, A.E. and I.M. Smith. 1982. Distribution of polygalacturonase, total phenolic substances, polyphenol oxidases and peroxidases in rot zones of sweet potato. Plant Pathol. 31:119122.

Azhar, A. and M.K. Hamdy. 1981. Alcohol fermentation of sweet potato. I. Acid hydrolysis and factors involved. Biotechnol. Bioeng. 23:879-886

Benjamin, N.D. and M.W. Montgomery. 1973. Polyphenol oxidase of Royal Ann cherries: Purification and characterization. J. Food Sci. 38:799-806.

Bloem, E., A. Riemenschneider, J. Volker, J. Papenbrock, A. Schmidt, I. Salac, S. Haneklaus, and E. Schnug. 2004. Sulphur supply and infection with Pyrenopeziza brassicae influence L-cysteine desulphydrase activity in Brassica napus L. J. Expt. Bot. 55:2305-2312. 
Duan, X.W., Y.L. You, X.G. Su, H.X. Qu, D.C. Joyce, and Y.M. Jiang. 2007. Influence of the nitric oxide donor, sodium nitroprusside, on lipid peroxidation and anti-oxidant activity in pericarp tissue of longan fruit. J. Hort. Sci. Biotechnol. 82:467-473.

Gao, S.P., K.D. Hu, L.Y. Hu, Y.H. Li, Y. Han, H.L. Wang, K. Lv, Y.S. Liu, and H. Zhang. 2013. Hydrogen sulfide delays postharvest senescence and plays an antioxidative role in freshcut kiwifruit. HortScience 48:1385-1392.

García-Mata, C. and L. Lamattina. 2010. Hydrogen sulphide, a novel gasotransmitter involved in guard cell signalling. New Phytol. 188:977984.

Haneklaus, S., E. Bleom, and E. Schnug. 2007. Sulfur and plant disease. In: Datnoff, L., W. Elmer, and D. Huber (eds.). Mineral elements and plant disease. APS Press, St Paul, MN.

Harrison, H.F., Jr., J.K. Peterson, C.A. Clark, and M.E. Snook. 2001. Sweetpotato periderm components inhibit in vitro growth of root rotting fungi. HortScience 36:927-930.

Hodges, D.M. and P. Toivonen. 2008. Quality of fresh-cut fruits and vegetables as affected by exposure to abiotic stress. Postharvest Biol. Technol. 48:155-162.

Hu, L.Y., S.L. Hu, J. Wu, Y.H. Li, J.L. Zheng, Z.J. Wei, J. Liu, H.L. Wang, Y.S. Liu, and H. Zhang. 2012. Hydrogen sulfide prolongs postharvest shelf life of strawberry and plays an antioxidative role in fruits. J. Agr. Food Chem. 60:8684 8693.

Jin, Z., J. Shen, Z. Qiao, G. Yang, R. Wang, and Y. Pei. 2011. Hydrogen sulfide improves drought resistance in Arabidopsis thaliana. Biochem. Biophys. Res. Commun. 414:481-486.

Jin, Z., S. Xue, Y. Luo, B. Tian, H. Fang, H. Li, and Y. Pei. 2013. Hydrogen sulfide interacting with abscisic acid in stomatal regulation responses to drought stress in Arabidopsis. Plant Physiol. Biochem. 62:41-46.

Lana, M.M. and L.M.M. Tijskens. 2006. Effects of cutting and maturity on antioxidant activity of fresh-cut tomatoes. Food Chem. 97:203-211.

Lazar, E.E., R.B. Wills, B.T. Ho, A.M. Harris, and L.J. Spohr. 2008. Antifungal effect of gaseous nitric oxide on mycelium growth, sporulation and spore germination of the postharvest horticulture pathogens, Aspergillus niger, Monilinia fructicola and Penicillium italicum. Lett. Appl. Microbiol. 46:688-692.

Leshem, Y.Y., R.B.H. Wills, and V.V.V. Ku. 1998. Evidence for the function of the free radical gas nitric oxide (NO•) as an endogenous maturation and senescence regulating factor in higher plants. Plant Physiol. Biochem. 36:825-833.

Lisjak, M., T. Teklic, I.D. Wilson, M. Whiteman, and J.T. Hancock. 2013. Hydrogen sulfide: Environmental factor or signalling molecule? Plant Cell Environ. 36:1607-1616.

Mars, R.W. 1929. Investigations on the fungicidal action of sulphur. III. Studies on the toxicity of sulphuretted hydrogen and on the interaction of sulphur with fungi. Jour. Pom. Hort. Sci. 7:237-250.

Martín-Belloso, O., R. Soliva-Fortuny, and G. Oms-Oliu. 2007. Fresh-cut fruits, p. 879-899. In: Hui, Y.H. (ed.). Handbook of food products manufacturing. Principles, bakery, beverages, cereals, cheese, confectionary, fats, fruits, and functional foods. John Wiley \& Sons, NJ.

Meilgaard, M., G.V. Civille, and B.T. Carr. 1991. Sensory evaluation techniques. 2nd Ed. CRC Press Inc., Boca Raton, FL. p. 213-215.

Miller, G.L. 1959. Use of dinitrosalicylic acid reagent for determination of reducing sugar. Anal. Chem. 31:426-428

Mishra, B.B., S. Gautam, and A. Sharma. 2013. Free phenolics and polyphenol oxidase (PPO): The factors affecting post-cut browning in eggplant (Solanum melongena). Food Chem. 139:105-114.

Rausch, T. and A. Wachter. 2005. Sulfur metabolism: A versatile platform for launching defence operations. Trends Plant Sci. 10:503-509.

Ray, R.C. and V. Ravi. 2005. Post harvest spoilage of sweet potato in tropics and control measures. Crit. Rev. Food Sci. Nutr. 45:623-644.

Rennenberg, H. 1983. Role of O-acetylserine in hydrogen sulfide emission from pumpkin leaves in response to sulfate. Plant Physiol. 73:560-565

Reyes, L.F., J.E. Villarreal, and L. CisnerosZevallos. 2007. The increase in antioxidant capacity after wounding depends on the type of fruit or vegetable tissue. Food Chem. 101:1254-1262.

Scott, G.J. 1992. Transforming traditional food crops: Product development for roots and tubers, p. 3-20. In: Scott, G.J., S. Wiersema, and P.I. Ferguson (eds.). Product development for roots and tuber crops. Vol. 1. Asia International Potato Center (CIP), Lima, Peru.

Sekiya, J., A. Schmidt, L.G. Wilson, and P. Filner. 1982. Emission of hydrogen sulfide by leaf tissue in response to L-cysteine. Plant Physiol. $70: 430-436$
Tanaka, Y. and I. Uritani. 1977. Synthesis and turnover of phenylalanine ammonia lyase in root tissue of sweet potato injured by cutting. Eur. J. Biochem. 73:255-260.

Thompson, D.P. 1981. Chlorogenic acid and other phenolic compounds in fourteen sweet potato cultivars. J. Food Sci. 46:738-740.

Uritani, I. 1998. Biochemical comparison in storage: Stress response between sweetpotato and cassava. Trop. Agr. 75:177-182.

Wang, R. 2012. Physiological implications of hydrogen sulfide: A whiff exploration that blossomed. Physiol. Rev. 92:791-896.

Wills, R.B.H., V.V.V. Ku, and Y.Y. Leshem. 2000. Fumigation with nitric oxide to extend the postharvest life of strawberries. Postharvest Biol. Technol. 18:75-79.

Wilson, L.G., R.A. Bressan, and P. Filner. 1978. Light-dependent emission of hydrogen sulfide from plants. Plant Physiol. 61:184-189.

Woolfe, J.A. 1992. Sweet potato: An untapped food resource. Camb. Univ. Press, Cambridge.

Yin, J., S. Bai, F. Wu, G. Lu, and H. Yang. 2012. Effect of nitric oxide on the activity of phenylalanine ammonia-lyase and antioxidative response in sweet potato root in relation to wound-healing. Postharvest Biol. Technol. 74:125-131.

Zhang, H., L.Y. Hu, K.D. Hu, Y.D. He, S.H. Wang, and J.P. Luo. 2008. Hydrogen sulfide promotes wheat seed germination and alleviates the oxidative damage against copper stress. J. Integr. Plant Biol. 50:1518-1529.

Zhang, H., S.L. Hu, Z.J. Zhang, L.Y. Hu, C.X. Jiang, Z.J. Wei, J. Liu, H.L. Wang, and S.T. Jiang. 2011. Hydrogen sulfide acts as a regulator of flower senescence in plants. Postharvest Biol. Technol. 60:251-257.

Zhang, H., H. Jiao, C.X. Jiang, S.H. Wang, Z.J. Wei, J.P. Luo, and R.L. Jones. 2010. Hydrogen sulfide protects soybean seedlings against drought-induced oxidative stress. Acta Physiol. Plant. 32:849-857.

Zhang, H., J. Tang, X.P. Liu, Y. Wang, W. Yu, W.Y. Peng, F. Fang, D.F. Ma, Z.J. Wei, and L.Y. Hu. 2009. Hydrogen sulfide promotes root organogenesis in Ipomoea batatas, Salix matsudana, and Glycine max. J. Integr. Plant Biol. 51:1084-1094.

Zheng, X., T. Yu, R. Chen, B. Huang, and V.C. Wu. 2007. Inhibiting Penicillium expansum infection on pear fruit by Cryptococcus laurentii and cytokinin. Postharvest Biol. Technol. 45:221-227. 